\title{
Isolation of necrotoxigenic Escherichia coli from paediatric patients with acute diarrhoea
}

Most Escherichia coli strains are commensal inhabitants of the gastrointestinal tract, but some strains can be pathogenic. These are characterized by the production of different factors that contribute to virulence. In the case of necrotoxigenic E. coli (NTEC), these may include fimbrial or afimbrial adhesins, the siderophore aerobactin, and two toxins cytotoxic necrotizing factor (CNF) and the cytolethal distending toxin (Van Bost et al., 2003). CNFs are E. coli protein toxins inducing cell multinucleation and enlargement in tissue cultures, and necrosis in rabbit skin (Falbo et al., 1992). Two types of CNF have been identified, each of them being genetically linked to several other specific virulence markers, a situation that allows the definition of two distinct homogeneous categories of NTEC called NTEC-1 and NTEC-2. CNF1 and CNF2 are highly homologous holoproteins containing 1014 amino acids that exert both lethal and necrotic activities in vivo, and induce multinucleation and actin stress fibres in cell cultures. The activity of CNFs on mammal cells is due to their ability to constitutively activate by deamidation the Rho proteins, a family of small GTPases that regulate the physiology of the cell cytoskeleton (De Rycke et al., 1999).
Although discovered for the first time in neonatal enteritis (Caprioli et al., 1983), the participation of NTEC-1 in diarrhoeal diseases in humans has not been as clearly established as in extra-intestinal infections (Bisicchia et al., 1985). However, several clinical and epidemiological observations suggest that NTEC-1 do exert a pathogenic effect on the intestine, at least in young children. Firstly, two separate outbreaks of neonatal diarrhoea that occurred in two different Spanish hospitals were reported to be associated with NTEC- 1 of the $06: \mathrm{K}$ 13 serotype (Blanco et al., 1992a), which provides a good indication about the potential role of NTEC-1 in enteritis in infants. Secondly, pyelonephritic E. coli strains were incriminated in two cases of ecchymotic colitis in newborn infants (Gaillard et al., 1989).

To date, there has been no report of a comprehensive case-control epidemiological study of the association of CNF-producing E. coli strains with human diarrhoeal diseases in India. Therefore, such an association was investigated by searching for $c n f$ genes among $300 \mathrm{E}$. coli isolates from 100 children with acute diarrhoea and 200 matched controls by PCR, with further characterization by serogrouping. The study group consisted of 100 children of less than 3 years of age with acute watery diarrhoea, and 200 children matched for age and sex represented the control group. Fresh stool specimens were collected from diarrhoeal patients and control patients and were inoculated on MacConkey agar and eosin methylene blue agar plates. Colonies were confirmed as E. coli using standard biochemical tests. Strains of E. coli isolated from the study group and control group samples were sent to the Central Research Institute, Kasauli, Himachal Pradesh, India, and serogrouped. All the isolates were examined by PCR for the presence of $c n f 1$ and $c n f 2$ genes encoding $\mathrm{CNF} 1$ and $\mathrm{CNF} 2$, respectively. Bacterial DNA was isolated as described by Reischl et al. (2002). Briefly, an overnight bacterial culture was suspended in $300 \mu \mathrm{l}$ lysis buffer composed of $10 \mathrm{mM}$ Tris/ $\mathrm{HCl}$ (pH 8.0), 1 \% Triton X-100, $0.5 \%$ Tween 20 and $1 \mathrm{mM}$ EDTA. The bacterial suspension was heated at $100{ }^{\circ} \mathrm{C}$ for $10 \mathrm{~min}$ and then centrifuged at $1000 \mathrm{~g}$ for $2 \mathrm{~min}$ to sediment the debris. The supernatant was used as a template for amplification reactions. Gene regions encoding CNF1 and CNF2 (cnf1, cnf2) were amplified for each bacterial isolate using specific primers. The master mix consisted of $50 \mathrm{mM} \mathrm{KCl}, 1 \mu \mathrm{M}$ Tris/ $\mathrm{HCl}, 1.5 \mathrm{mM} \mathrm{MgCl} 2,100 \mu \mathrm{M}$ dNTPs and $1 \mathrm{U}$ Taq polymerase. A total of $5 \mu \mathrm{l}$ DNA template was added to $45 \mu \mathrm{l}$ master mix and $0.1 \mu \mathrm{M}$ primer pairs. Primers and

Table 1. Primers and cycling conditions used in the amplification of specific gene fragments for the cnf1 and cnf2 genes responsible for toxin production

\begin{tabular}{|c|c|c|c|c|c|}
\hline $\begin{array}{l}\text { Pathogenic factor } \\
\text { (encoding gene) }\end{array}$ & Primer & Primer sequences $\left(5^{\prime} \rightarrow 3^{\prime}\right)$ & $\begin{array}{l}\text { Product size } \\
\text { (bp) }\end{array}$ & Cycling conditions & Reference \\
\hline CNF1 (cnfl) & $\begin{array}{l}\text { CNF 1a } \\
\text { CNF 1b }\end{array}$ & $\begin{array}{l}\text { GCTCAACGAGACTATGCTCTG } \\
\text { ACGCTGCTAAGTACCTCCTGG }\end{array}$ & 278 & $\begin{array}{l}95{ }^{\circ} \mathrm{C} \text { for } 30 \mathrm{~s}, 5 \text { cycles of } 72{ }^{\circ} \mathrm{C} \\
\text { for } 1 \mathrm{~min} ; 20 \text { cycles of } 95{ }^{\circ} \mathrm{C} \text { for } \\
30 \mathrm{~s}, 63^{\circ} \mathrm{C} \text { for } 30 \mathrm{~s}, 72{ }^{\circ} \mathrm{C} \text { for } 30 \mathrm{~s} \text {; } \\
72{ }^{\circ} \mathrm{C} \text { for } 5 \text { min final extension. }\end{array}$ & $\begin{array}{l}\text { Falbo et al. } \\
(1992)\end{array}$ \\
\hline CNF2 (cnf2) & $\begin{array}{l}\text { CNF 2a } \\
\text { CNF 2b }\end{array}$ & $\begin{array}{l}\text { GTGAGGCTCAACGAGATTATGCACTG } \\
\text { CCACGCTTCTTCTTCAGTTGTTCCTC }\end{array}$ & 839 & $\begin{array}{l}5 \text { cycles of } 95{ }^{\circ} \mathrm{C} \text { for } 30 \mathrm{~s}, 72{ }^{\circ} \mathrm{C} \\
\text { for } 1 \mathrm{~min} ; 20 \text { cycles of } 95{ }^{\circ} \mathrm{C} \\
\text { for } 30 \mathrm{~s}, 63{ }^{\circ} \mathrm{C} \text { for } 30 \mathrm{~s}, 72{ }^{\circ} \mathrm{C} \text { for } \\
30 \mathrm{~s} ; 72{ }^{\circ} \mathrm{C} \text { for } 5 \text { min final } \\
\text { extension. }\end{array}$ & $\begin{array}{l}\text { Pass et al. } \\
(2000)\end{array}$ \\
\hline
\end{tabular}


amplification conditions for the pathogenic gene coding regions as shown in Table 1 were employed under the conditions described elsewhere (Falbo et al., 1992; Pass et al., 2000). Amplified gene products were verified by gel electrophoresis ( $2 \%$ agarose) at $80 \mathrm{~V}$ for $90 \mathrm{~min}$ and visualized under UV light. Reference strains, BM2-1 (cnf1) and B20A (cnf2), representing each of the amplified genes were used.

In the present study, NTEC (12\%) was isolated only from diarrhoeic children, thus demonstrating the association of NTEC with diarrhoea in children in our region and this was found to be highly significant as compared to the control subjects by Fisher exact probability test $(P<0.0000012)$. The 12 NTEC strains showed an equal distribution of $c n f 1$ and cnf2 genes. This was in contrast to many reports (Blanco et al., 1992a; De Rycke et al., 1999), where it was demonstrated that $\mathrm{CNF} 1$ alone was responsible for human diarrhoea. However, a study in South Africa (Obi et al., 2004) showed a prevalence of $21 \%$ NTEC where CNF2 $(17.3 \%)$ was recovered at higher frequency than CNF1 (3.5\%).

Recently, CNF3, a novel member of the CNF family, has been described in NTEC from sheep and goats, which shares about $70 \%$ sequence identity with CNF1. CNF3 is reported to activate RhoA similar to $\mathrm{CNF} 1$ and $\mathrm{CNF} 2$, but is reported to have a much stronger activity than CNF1 (Stoll et al., 2009). Also the association of the $c n f 3$ gene with eae and $e h x A$ genes suggests that $c n f 3$ NTEC strains might be pathogenic for humans (Orden et al., 2007). Identification of $c n f 3$ gene was not included in our study as the role of this gene in the pathogenesis of diarrhoea in humans is yet to emerge.

NTEC in our present study belonged to five different serogroups. The serogroups isolated in the study group were O12(5), O4(3), O78(2), O29 and O35. The serogroup $\mathrm{O} 12(41.7 \%)$ was the predominant CNF-producing diarrhoeagenic NTEC in our study. All the isolated serogroups, except $\mathrm{O} 35$, in the present study have been reported elsewhere as being among E. coli strains that produce CNF (Blanco et al., 1992b; Mainil et al., 1999). In those studies, the NTEC serogroups were isolated either from stool samples of humans or animals, or were found in isolates from human extraintestinal infections. Also, NTEC isolated from animals and humans can belong to the same serogroups and produce or carry genes encoding fimbrial and afimbrial adhesions (Mainil et al., 1999). Moreover, NTEC from man and animals appears to be highly related according to available molecular markers, which indicates that domestic animals could be reservoirs of NTEC strains (De Rycke et al., 1999). The isolation of NTEC from some of the rivers investigated may confirm the faecal contamination of these water sources by grazing cattle, and raises the question of possible zoonotic infections (Obi et al., 2004).

There is presently ample well-founded evidence that NTEC strains could be incriminated as pathogens in both humans and domestic animals. The pathogenicity of NTEC previously designated uropathogenic is in fact not restricted to the urinary tract but encompasses the digestive tract also.

\section{Kannaiyan Kavitha, ${ }^{1}$ K. Prabhakar, ${ }^{2}$ S. Rajendran, ${ }^{2}$ B. Uma ${ }^{2}$ and Y. Lakshmi Sarayu ${ }^{2}$}

${ }^{1}$ Department of Microbiology, Aarupadai Veedu Medical College, Puducherry, India

${ }^{2}$ Department of Microbiology, Rajah Muthiah Medical College, Annamalai University, Tamil Nadu, India

Correspondence: Kannaiyan Kavitha (kavikgk@yahoo.co.in)

Bisicchia, R., Ciammarughi, R., Caprioli, A., Falbo, V. \& Ruggeri, F. M. (1985). Toxin production and haemagglutination in strains of Escherichia coli from diarrhoea in Brescia, Italy. J Hyg 95, 353-361.

Blanco, J., Gonzalez, E. A., Espinosa, P., Blanco, M., Garabal, J. I. \& Alonso, M. P. (1992a). Enterotoxigenic and necrotizing Escherichia coli in human diarrhoea in Spain. Eur J Epidemiol 8, 548-552.

Blanco, J., Blanco, M., Alonso, M. P., Blanco, J. E., Garabal, J. I. \& Gonzalez, E. A. (1992b). Serogroups of Escherichia coli strains producing cytotoxic necrotizing factors
CNF1 and CNF2. FEMS Microbiol Lett 96, 155159.

Caprioli, A., Falbo, V., Roda, L. G., Ruggeri, F. M. \& Zona, C. (1983). Partial purification and characterization of an Escherichia coli toxic factor that induces morphological cell alterations. Infect Immun 39, 1300-1306.

De Rycke, J., Milon, A. \& Oswald, E. (1999). Necrotoxic Escherichia coli (NTEC): two emerging categories of human and animal pathogens. Vet Res 30, 221-233.

Falbo, V., Famiglietti, M. \& Caprioli, A. (1992). Gene block encoding production of cytotoxic necrotizing factor 1 and hemolysin in Escherichia coli isolates from extraintestinal infections. Infect Immun 60, 2182-2187.

Gaillard, J. L., Cheron, G., Mougenot, J. F., Deslys, J. P., Nezelof, C., Veron, M. \& Schmitz, J. (1989). Pyelonephritic Escherichia coli strains as intestinal pathogens in two newborn infants. Lancet 333, 327-328.

Mainil, J. G., Jacquemin, E., Pohl, P., Fairbrother, J. M., Ansuini, A., Le Bouguenec, C., Ball, H. J., De Rycke, J. \& Oswald, E. (1999). Comparison of necrotoxigenic Escherichia coli isolates from farm animals and from humans. Vet Microbiol 70, 123-135.

Obi, C. L., Green, E., Bessong, P. O., de Villiers, B., Hoosen, A. A., Igumbor, E. O. \& Potgieter, N. (2004). Gene encoding virulence markers among Escherichia coli isolates from diarrhoeic stool samples and river sources in rural Venda communities of South Africa. Water SA 30, 3742.

Orden, J. A., Dominguez-Bernal, G. Martínez-Pulgarín, S., Blanco, M., Blanco, J. E., Mora, A., Blanco, J. \& de la Fuente, R. (2007). Necrotoxigenic Escherichia coli from sheep and goats produce a new type of cytotoxic necrotizing factors $(\mathrm{CNF} 3)$ associated with eae and $e h x A$ genes. Int Microbiol 10, 47-55.

Pass, M. A., Odedra, R. \& Batt, R. M. (2000). Multiplex PCRs for identification of Escherichia coli virulence genes. J Clin Microbiol 38, 20012004.

Reischl, U., Youssef, M. T., Kilwinski, J., Lehn, N., Zhang, W. L., Karch, H. \& Strobine, N. A. (2002). Real time fluorescence PCR assays for the detection and characterization of Shiga toxin, intimin, and enterohemolysin genes from Shiga toxin-producing Escherichia coli. J Clin Microbiol 40, 2555-2565.

Stoll, T., Markwirth, G., Reipschlager, S. \& Schmidt, G. (2009). A new member of a growing toxin family - Escherichia coli cytotoxic necrotizing factor 3 (CNF3). Toxicon 54, 745-753.

Van Bost, S., Jacquemin, E., Oswald, E. \& Mainil, J. (2003). Multiplex PCRs for identification of necrotoxigenic Escherichia coli. J Clin Microbiol 41, 4480-4482. 